\title{
Introduction: Borders, Informality, International Trade and Customs
}

\author{
"The books of administrators are never of any use to the State, because when they talk about a \\ remedy they never go to the heart of the problem. The actions of individuals, heads of organized \\ bands, vagabonds and others, who attract public odium, are more reliable, because they reveal, \\ usually to sovereigns, weak points in the government.”
}

Political testament written in prison by the smugglers’ leader Louis Mandrin ${ }^{1}$ - Ange Goudar, 1756

Thomas Cantens, World Customs Organization (Belgium), Centre Norbert Elias (France), thomas.cantens@wcoomd.org

Robert Ireland, World Customs Organization (Belgium), robert.ireland@wcoomd.org

Gael Raballand, World Bank, graballand@worldbank.org

This special issue deals with the "informal" cross-border trade in goods. Trading goods is an original human activity that precedes borders (Renfrew, 1969). With the rise of nation-states with demarcated political boundaries, trade that crosses borders became regulated by government institutions such as Customs, with tariffs, quotas, or outright prohibitions. While borders are perhaps not quite "the dead, the fixed, the undialectical, the immobile" (Foucault, 1970, p. 70), they are a formal structure that places less flexibility on trade activities. Focusing on informality thus provided an opportunity to reflect on the governance of international trade, which has been marked by increasing consolidation of its rules in the last decades. Informal cross-border trade affects the symbolic power of the State, particularly where the State takes one of its more concrete forms, as "the borders." Indeed, at borders, where commodities flows are regulated, informal trade forces governments to balance or choose between rule avoidance with economic contribution, as well as social relations. This tension between the economic, political and social dimensions of informal trade at borders is reflected in this special issue.

Any paper that discusses informality must confront its definition. Informality can escape state control, and researchers do not necessarily want to be similarly outflanked. The term "informal" appeared for the first time in a report of the International Labor Office (1972) and in an article by Keith Hart (1973), an anthropologist who had worked in Ghana a few years earlier and "succeeded" in trade in local markets (Hart, 2002). Throughout its use, the word "informal" has been attached to "labor", "sector", "economy", "trade" and "practices" 2 . Academics have worked on this in vogue concept for over 30 years, and whose use has

\footnotetext{
${ }^{1}$ Louis Mandrin (1724-1755) was convicted of smuggling and counterfeiting in France. There has been more accounts and portrayals of him than of any other smuggler, robber or criminal during the French Ancien Régime (Lusebrick, 1979).

${ }^{2}$ Academic literature on informality is wide, and making a review of it is out of the scope of this paper. The way academics deal with informality is mainly rooted in their disciplines. Economists tend to attach the word "informal" to singularized entities like the "sector", the "operators" or the "entrepreneurs." Political scientists or anthropologists describe "practices" as informal. For "informal practices" related to economic questions, see for instance Ledeneva (2006) whose approach is based on a typology of different kinds of practices in Russia or the project The Global Encyclopaedia of Informality directed also by Prof. Ledeneva (https://www.ucl.ac.uk/ssees/research/funded-research-projects/informal-practices).
} 
become so widespread as to be disputed for that very reason (Hart, 2005; Klein, 1999). We seem to be suffering from an overdose of informality, a feeling of having exhausted the use of a concept while still not knowing how to manage without it. In turning their attention to the situation of international trade, merely because policymakers, development experts and civil servants in the field use the concept of informality, researchers may find themselves in the tricky position of using a concept that has become part of the collective scientific psyche without adhering to a definition or participating in the controversies relating to it.

Perhaps the first question is whether looking for (or at) a definition of "informal" is vital as a starting point of the reflection? A definition could of course be minimalist - "informal" is not within the forms required by an authority - but it would be tautological and the question is whether it teaches us something.

If informality is no longer defined in itself, but in relation with something else (statistics, taxation, law, quantity, size of business, ethnicity, the "local”) or as ordering a typology (among kinds of businesses, social relations or relationships with the State), we may lose part of the diversity of the concept. For example, it is common to say that informal trade is the trade that is not reported in national statistics and that this non-report constitutes a definition of informality. If the first part of the sentence may be partially true - an informal trade transaction may be partially informal and thus partially reported in national statistics -, the second part of the sentence - identifying the non-report to informality - is a methodological choice assuming that informality will be explored quantitatively. This is legitimate as an exploratory choice but this cannot be a "definition" of informal trade. If it was the case, this definition would assume that "statistics" have some kind of necessary pre-existence and informality would have a negative dimension according to what should be done (reporting quantitatively) and would be a hole to be filled in knowledge.

Taxation is another example of the existing continuum between informal and formal activities. Taxation was often represented as a dividing line between formal and informal ${ }^{3}$ (MacGaffey, 1998), but cross-border traders who are represented by the authorities as "informal" pay some taxes or fully pay certain taxes and not others. One can be "informal" according to a specific regulation and cannot be so for another: Lautier (1995) exposes the case of traders who are identified at the municipality and pay the required local taxes but do not pay for social security. The size of the company ${ }^{4}$ is not always admissible as a criterion defining the informal sector. For instance, a merchant working in the formal sector uses his logistical means or partners with informal traders to diversify his business and achieve greater profit margins via smuggling or importing without submitting a declaration to Customs. The case is well known by Customs officers and is described in the following articles. In general, it is now well accepted that the distinction between "formal" and "informal" does not apply to operators who often divide their activities between the two sectors (Ødegaard 2008). Meagher (2013) highlighted what has changed over the last twenty years about the linkages between formal and informal: the growing integration of the informal economy into the global value chains. Thus, to some extent, the increasing contribution of informality to international trade. This contribution is taking place at two levels, production - which is the best known level and trade itself.

The informal economy is substantial in most countries. Among the 162 countries studied by Schneider et al. (2010) during the period 1999-2007, 107 had an estimated informal share greater than or equal to $30 \%$ of total GDP, including 18 with a share over $50 \%$. These

\footnotetext{
${ }^{3}$ Taxation is a «traditional » dividing line in public policies. In general, most governments strive to establish a specific taxation applied to informal traders or make them formal.

${ }^{4}$ Informal entrepreneurs are often represented as small businesses with almost no financial strength.
} 
national informal economies are partly based on international trade of goods, be it formal or informal, land cross-border trader or trade with a wider geographic extension (Dongala, 1993).

Informality is more embedded into globalization. As a consequence, researcher on informality has evolved from the dualistic distinction between informal and formal sectors at the national levels to the impacts of informality on global governance and markets (Meagher 2013).

Faced with the difficulty of defining informality, it may be necessary to accept, at least as a starting point for reflection, that our knowledge on informality is above all intuitive: we can all recognize "informal" practices whenever we meet them but we cannot all accept the same definition of informality (at least a definition that brings something more than a tautology). This intuition about informality is not rooted in time and space. There is a reason why we do not deceive ourselves when we call something "informal", or why we understand what border officials mean when they speak of "informal operators". This reason is that there is something in the "informal" that makes us immediately reflect on authority: when we are in contact with informality, informality forces us to identify the presence of authority and takes some distance from it. In other words, there is something in the idea of informality that is grounded by a common meaning directly accessible and that we can identify as the invitation to take a step aside and question ourselves on the authority, particularly in this special issue, the state authority that is materialized by borders.

The starting point of this issue is therefore what happens at borders, especially their porosity and how they are controlled, from the point of view of the goods. The heuristic power of informal trade is that it makes us think of borders as much as an opportunity for enrichment as an "anomaly" in a basic human relationship that is the material exchange. This does not mean the weakening of borders, neither as a State institution gathering different control apparatuses, nor as a political concept. This means adopting also an epistemological perspective: to which extent do the approaches and questioning adopted on informality by researchers, experts, policymakers and field officers unveil the way we think of borders and trade governance? The questioning can thus be summarized as follows: to what extent does the opposition between formal and informal represent a pattern of thought that forms some representations of the relationships between borders and exchange of goods and shape public policies and governance? In Louis Mandrin's words, what interests us here is as much what happens at borders for goods as what state actors and researchers unveil about themselves when they reflect on informal cross-border trade.

This introduction follows two objectives: i) to consider a set of questions addressed to and by border control services ${ }^{5}$, and ii) to examine what the formal / informal pattern applied to cross-border trade brings to the episteme of the border. A final section presents the different articles of this issue by connecting them to the framework developed in the two previous sections.

\section{The questions addressed to and by those who control the borders}

There are three main questions for those who control the borders and are concerned by informal trade: the relevance of a distinction between "informality" and "smuggling", the

\footnotetext{
${ }^{5}$ The World Customs Organization (WCO) organized, jointly with the World Bank, an international conference on "Informality, International Trade and Customs", held in June 2013 in Brussels. This conference brought together a hundred or so Customs officials and academics, anthropologists, economists, and political scientists. It was partially funded by the Korea Customs Service. One of the aims of this conference was to sensitize researchers to field dilemmas and issues faced by officials in charge of enforcing law at borders and to share with these officials a reflection on the political, sociological and ethical dimensions of their functions when confronted by the issue of "informality".
} 
economic and social legitimacy of informal trade and the "solutions" to eliminate or contain informal trade. From an analytical perspective, what is at stake, in this introduction, is not to answer these questions but to distinguish the political and epistemological issues they convey.

\section{The legal question: why talk about informality when law calls it smuggling?}

Smuggling, undeclared importation, fraud as to value, origin or quantity, the Customs legislation and codes have many names for "informality" that make officials doubt the usefulness of the concept. That question, put by a number of Customs officials, is, however, answered by their own practice: on the ground, Customs officials themselves use the term "informals" to denote certain categories of users, importers, and forwarding agents.

Whether applied effectively, efficiently, and fairly, or not, the contemporary reality of cross-border trade regulations are disregarded by some traders. In other words, some traders do not comply with border laws and thus become smugglers. Informal trade is a sibling of smuggling, or perhaps its cousin. The nomenclature itself is relatively new (Hart, 1973; ILO, 1972) and the meaning is subject to differing interpretations, frequently based on ideology. To characterize informal trade as being non-compliant with border agency requirements, however, is to date it historically. In the absence of a State and its revenue collector function, "informal trade" is merely "trade". There is nothing pejorative from a political or legal perspective about traders that exchange goods across borders that do not exist or do not pay taxes that have not been levied. Thus, the characterization of informal trade as non-compliant can only be made after the rise of the State, border controls, and the power to tax.

There are many motives behind non-compliance with border rules. Smuggling can be understood as relatively intentional and based on the wish to pay no or fewer taxes, or to profit from trade in prohibited goods such as crystal meth (Gilligan, 2008). The motive can, however, be more nuanced or benign. The motive can be survival if the micro-trader is so poor that any reduction in income leads to oblivion. The motive can be refusal to participate in the corruption of a revenue collector who demands a bribe or an unreasonable payment beyond what the Customs code requires. The despotism of a State which renders all unto Caesar can give some legitimacy for non-compliance. Informal trade can emerge and expand because of the multifaceted failures of a State. Non-compliance can perhaps accentuate neoliberalism or be exploited by a libertarian "tea party" advocating that everyone rely only on themselves and that government is unnecessary.

The multiple and local uses of the term "informals" remind us that the law is always a social construction, even if it manifests itself in an intangible or timeless form (Bourdieu, 1986). What is more, Customs officials are not simply neutral enforcers of the law. They participate in its development in international bodies like the WCO, which establishes administrative standards, or as expert advisers to funding agencies. Because they know the terrain and are the repository of the administration's attempts to combat fraud, they also know what techniques are viable, and serve as technical consultants to governments. Despite the effective participation of Customs officials in the elaboration of legislation, there remains the difficulty of conceptualizing "informals" primarily outside the legal framework.

\section{The economic question: even if informal activities are illegal, can they be legitimate?}

We have confined ourselves to trade in "legal" goods, to the exclusion of products in which trade is prohibited or very restricted (arms, narcotics, etc.), so as to participate in the debate about the "legitimacy" of informal trade. With regard to international trade, the legitimacy of the informal sector rests more on the goods themselves than on practices claiming, or capable of claiming, political significance as rebellion against the State. By their nature as second-hand or low-value merchandise, the goods in question tend to be cheap and 
intended for the poor: clothing, both new from Asia and used from Europe, agricultural products, fresh comestibles, cattle and pesticides, as well as more urban products such as motorcycles, second- or third-hand vehicles, small luxury objects and cheap mobile telephones.

By restricting the field of study to "illegal" trade in "legal" merchandise, analysts can address more specifically the question of the construction of the illegality of the practices and the action of the State, which is the guarantor of the law but also of economic "development", linking judicial law to "the laws of economics": what is to be done about trade that is partly or wholly informal but remains confined to legal merchandise in circulation in a national and international environment based on free trade?

In "poor" countries, there is solid political support for informal trade, but the economic benefits of market scale are equally important, leading to a critical view of informal trade. Thus the common debate between the political legitimacy and the economic legitimacy of the informal sector is transposable in international trade. On the one hand, informal trade is seen as an expression of the dynamism of a given society, made evident by the inability of States to enforce the rules they proclaim and the ability of innovators to play with those rules and find opportunities for self-enrichment. Hernando de Soto (2000) contended that, in developing countries, enterprises are judged more on their ability to respond to and absorb bureaucratic practices than on the market relevance of their activity. One line of thought considers informal trade as the first positive sign of successful liberalization of the economy (Lourenço-Lindell, 2004). On the other hand, empirical and qualitative studies of funding methods and family and linguistic networks show that informal trade also exists as a system closed to competition and economically harmful to the population groups it is primarily supposed to serve. In one study conducted in Cameroon, "formal" traders complain of unfair competition: even "informal" traders complain of the growth of informal trading in some goods which has led to increased competition (Cantens et al., 2014).

The question of legitimacy therefore goes beyond the distinction made by Abraham and Van Schendel (2005), between what is "legal" and what is "lawful" or "licit". In their book about globalization and transnational crime, Abraham and Van Schendel proposed a conceptual framework, distinguishing some kind of a "state vision" ${ }^{6}$ that considers what is "legal" and the people vision on what is "licit": according to the authors, something may be illegal but licit. This distinction allows them to distinguish between cross-border criminal organizations and small traders crossing the borders with small quantities of commodities (who are part of "our" informal trade that is explored here). This real distinction suggests policymakers should adopt different and graduated responses to what is considered as illegal as a whole. What is at stake here, however, is a bit different.

The remaining question is that of the political legitimacy of informal trade. This questions the ruling elites, who are sometimes involved in informal trade, or the intellectuals, policymakers or international experts, who are not necessarily against informal trade. Informality is sometimes represented as the social response to rules and laws and considered as sufficient evidence that these rules and laws are missing their objectives. It is not about any "specter" (the one of transnational crime organizations) "haunting the globalization" (Abraham and Van Schendel, 2005, p. 2) that would be the "subtext" of stories relating the negative effects of globalization and fueling the fear of it. It is more a specter haunting the regulation of globalization, the specter of informality that questions the legitimacy of the rules

\footnotetext{
${ }^{6}$ By "state vision", we understand that they mean the views advocated by international experts from IGOs, national experts and civil servants working in and for state administrations.
} 
applied to trade. The questioning comes from within the group of "rulers" and does not oppose the "State" and the people. This is why informality, as a concept, is not necessarily linked to resistance and its political dimension does not oppose states to people ${ }^{7}$. On the contrary, the interest raised by informality among those who control borders is also a way to redefine the role of borders within the field of economics and the objective of a global regulation of the trade flows, within which borders controls are merely playing a role devoted to a local policing of international rules.

The bureaucratic question: what is to be done at the borders?

This is the third question asked by and to those who control the borders on behalf of states, and, sometimes, this is the first question they raise. We believe this question should be the last to be raised.

The border is a place of control but it is also a barrier to control: the liveliness of logistics networks working in informal activities cross borders in contrast to the barrier of the border for state services that cannot materially cross borders. The first risk is the revolt against the state and its representatives. Shifting informal trade to formal trade generates, among other things, an enforcement versus empathy dichotomy made famous by the "war on drugs". Should policymakers emphasize the carrot or the stick? Should informal traders be punished, or should government strive to work with them to find common solutions? Particularly punitive policies can, and have, tipped the informal sector into civil unrest (Ayadi, Benjamin, Bensassi, and Raballand, 2013), and from non-compliant trade in legal goods to trade in illegal goods. Not much is needed to reach this latter tipping point, as illegal goods are frequently more lucrative, especially when the gap between the risks diminishes.

Administrative issues are well known by border officials operating in the field and are developed in the following articles. These issues can be summarized as follows: how can the State enforce the law at borders - and thus remove any informal activity there - by using ways and means that are acceptable to the population whose main resource is the illegal trade in legal goods? We will see that, at all borders, states only seek to contain informal trade not combat it.

\section{Informal cross-border trade and the episteme of borders}

The second objective of this issue is to build on the challenge - merely bureaucratic at a first glance - informal trade poses to those who control the border, in order to understand how informal, applied to international trade in goods, also raises epistemological questions.

Borders as a point of negotiation within the global flows of wealth

As we have seen before, trade has an epistemological interest in itself in that it forces one to think of the border in economic terms. The questioning on borders is, to some extent, more extended when applied to flows of goods than for flows of people. With the exception of the question of migration control, that could be summarized as "why is someone forbidden to be somewhere?" and that is rarely addressed in this form, the questions are mainly about the effects of border closure policies. This is not the case for trade: borders are open and raise the question of trade intensity, in particular the balance between formal and informal trade practices from an economic perspective. This perspective has not always been treated by

\footnotetext{
${ }^{7}$ The reverse can be the case in borderlands. Roitman (2004) describes how, at the borders between Cameroon and Nigeria, Cameroonian informal traders ask for the help of the Cameroon government to counter foreign informal traders who compete with them.
} 
"non-quantitativist" researchers who have mainly focused their fieldwork on land borders and land cross-border trade between neighboring countries, with little interest for the integration of informal trade into globalization. With certain exceptions, such as Peraldi's studies (2001, 2007) or Hansen (2004), a great deal of research on informality and international trade, both in universities and in the development organizations, takes a minimalist approach in which informality is confined to frontier zones, very often land areas, between India and Bangladesh (Pohit et al., 2000; Skider, 2005), Mali and Algeria (Scheele, 2009), Benin and Nigeria (Flynn, 1997), Uganda and its neighbours (Titeca, 2010), and between Peru and Bolivia (Ødegaard, 2008). The trade conducted on either side of a border by inhabitants of frontier zones is a major subject of study in view of its impact in those zones, and beyond in some cases (Raballand et al., 2009, Mitra et al., 2012).

Nevertheless, it is also interesting to examine how certain "informal" traders fit into trade globalization processes, some of which are complex and distant, while others are nearer at hand but include unexpected population groups.

Indeed, a changing dynamic for informal trade in developing countries is the easier access to air transport and means of communication that facilitate links between linguistic and family communities across borders. Until very recently, it was predicted that the second-hand clothing trade would die out owing to competition from new clothing from Asia (Bredeloup et al., 2008). That has not been the case - quite the contrary - in the African ports, where second-hand clothing and used tyres are among the products which generate the most Customs revenue (Cantens et al. 2014). Access to international activity has thus become more democratic.

In these margins of legality, and because informal trade is highly organized, administrative agencies are faced with structures and individuals with which they can or must negotiate. As is the case in most of the articles presented in this issue, borders are places where the allocation of different kinds of wealth is negotiated: public wealth - Customs taxes and duties - and private wealth, be it the owner of the goods or the payment of bribes.

Everywhere, at local level, it is clear that Customs officials are simply applying the law yet negotiating its application with a section of the traders (Cantens, 2013). Everywhere, the administrative agencies are caught between the law, the international rules, the legitimacy of informal trade and the existence, as in every administration, of leeway in the creation of techniques for applying the law. It is within this triptych of law-technique-legitimacy that negotiation is played out.

The main difference is that the level of organization of the informal structures does not go beyond the local or national level, whereas the vast majority of technical control rules are elaborated in international agencies, either by recommendations from experts or by decisions taken in such organizations as the WCO or the WTO. While some traders in developing countries have gained access to globalized trade, access to its globalized regulation is still forbidden to them. This raises the unresolved issue of the representation at international level of traders classified as informal, given their weight in national politics.

Negotiating on the tax burden is no different with "informals" than with "formals": all Customs taxation policies are the outcome of negotiation in every country in the world. Even at the level of control, negotiation enters into the determination of illegality and the corresponding penalties. Customs officials often have the power to negotiate fines, and that can go even further in the case of liberal policies. The OECD itself recommends fiscal administrations to negotiate with the wealthiest taxpayers, since their tax situation is more 
international and more complex, and can never be fully taken into account by a national administration (OECD, 2009). Negotiation is not therefore confined to "informals" or the poor: it is the informal component of bureaucracy, the State's admission of powerlessness to regulate everything. By virtue of that fact, the informal sector has also been seen as a political apparatus in itself, in line with the idea of a state pragmatism that becomes "raison d'Etat" and imposes itself on the law in many circumstances.

\section{A praxeology of border control}

We seek to emphasize a praxeology of informal trade. Technique plays a crucial role in informality. Formal traders and informals are opposed to each other in their manner of adaption to administrative control, and this may be the core of the concept of informality: the technical inability to fit in with the control techniques. Techniques of administrative control have always more or less defined the boundary between formal and informal through their effect on practices in the private sector. The keeping of accounts and the obligation to keep them in specific forms are an example of a factor which makes it possible to classify a taxpayer as informal or not.

The role of technique in this respect has often been played down, however, since it seemed so obvious that an enterprise exists by virtue of its accounts, at least in the "developed" world (Chiapello, 2008), and that such accounting serves fiscal purposes. In France, accounting - the obligation to keep "books" - was imposed in the 17th Century. A royal decree of 1673 established the form of accounting ledger s and documents which large merchants had to keep. Nonetheless, as Gaignat de Laulnais $(1718)^{8}$ noted in his guide of commerce, no penalty was provided for non-compliance with that obligation (Gaignat, 1718, p. 46), since there was no administrative body responsible for monitoring it. The force of the formal expression lays elsewhere. It imposed itself in the judicial sphere because judgment was rendered in favour of a party that had documentary proof against one that did not.

This formal expression of commercial practice thus had legal force, but it also had symbolic force. Informality does, indeed, suppose new forms of trust. To make a technique at one and the same time a canon for the exercise of an occupation and an instrument of submission to the law is by no means self-evident and requires, first and foremost, a meeting of those who make the law and those who engage in that trade - if not the movement of the same persons from one world to the other, as has been the case in Europe since the 17th Century.

Today, people who are locally engaged in informal trade have no access to the organizations in which the law is discussed. The only official negotiation with representatives of the State is often about the tax burden on the goods concerned. Informal trade could once be understood solely as a reaction to public policies, and consisted in the avoidance of financial constraints or a more or less intentional ignorance of the rules. In both cases, governments responded with official policies, more or less effective but easily conceived: for example, establishing and negotiating the financial constraints together with the informal players by organizing them in associations.

The dynamics of action and reaction on the part of governments and informals is changing and resulting in growing awareness of the increasingly crucial role of technique in

\footnotetext{
${ }^{8}$ Gaignat de Laulnais was a French merchant in Nantes before teaching trade practices and writing a guide for traders. He is one of these numerous "merchants-intellectuals" who, between the mid-17th century and the mid18th century, built a kind of science of commerce, knowledge on trade based on their practical experience, and compiled it into guides of commerce (Hoock and al., 1993; Skornicki, 2006). The work of one of them, Jacques Savary, was quoted in American handbooks of accounting until the early 20 ${ }^{\text {th }}$ century (Parker, 1966).
} 
state control methodology. Informality is no longer solely a reaction to public policies, but simply the effect of those policies in a situation where the techniques employed, both in control and in trade, are increasingly important.

The liberalization of trade is a political constant which has been a global political project since the end of the Second World War. Nevertheless, and with regard to international trade in goods in particular, governments' security demands have increased, resulting in the imposition of new control practices which require the provision of more information and have greater recourse to technical means - both computer technology and legal and logistic techniques - and to more material resources. Faced with the greater complexity they have created, and simultaneously with this creation, liberal policies have invented new avoidance mechanisms for players regarded a priori as "compliant". Authorizations are granted which enable "good" trade players to comply with the increased demands more easily, or even not to comply with them but instead be inspected from time to time by the administration.

Free trade in the capitalist mode has the capacity to create complexity of regulation at the same time as simplification for certain players deemed a priori "above board". Such players, via their trade associations or their own international organizations, are party to negotiations with the State on the construction of the control techniques that will be applied to them (or not). That approach establishes a clear line between players whose commercial practices accord with those of the control administrations because the latter were established by reference to the former, and players whose commercial practices cannot be thought of in the language of state administration and technique.

Informal trade is thus no longer necessarily to be conceived in terms of compliance with the law but rather as lack of adaptation to control, or even the inability to take advantage of the opportunities for avoiding control which the law affords. That raises the question of the construction of legality, of the techniques involved, and of the status of those who participate in its construction.

\section{The "mathematisation" of borders}

The borders for goods are places that are strongly "mathematised", as noted by geographers Cowen (2010) and Martin (2012), about the growth of logistics issues and calculations. The Doing Business reports, the indices of the World Economic Forum or the World Bank Logistics Performance Index, as well as the use of local "dwell times" indicators in development projects on border infrastructure are evidence that borders become a numerical space. Mathematisation of borders has a political impact by representing how a "good" border should "look like", in terms of dwell times, efficient and predictable border controls, and services offered to the merchants, including Customs control, which is increasingly considered as a "service" to "users" .

Of the techniques used in rendering society governable, quantification plays an ever greater part (Ogien, 2010). The question raised by informal trade is what to do about the unmeasurable in societies where quantification is increasingly important. "What cannot be measured does not exist": Niels Bohr's dictum is more or less the leitmotif of public policy and reform of state structures in accordance with the principles of "new public management".

By its nature, informal trade cannot be measured, but its non-existence is impossible to accept and so are its effects impossible to ignore. Having been adapted to what is measurable, ways of thinking about informal trade have difficulty in conceptualizing it other than with a

\footnotetext{
${ }^{9}$ See, for instance, Michaels (2009) on the role of the World Bank Doing Business reports on the evolution of national laws.
} 
view to its disappearance. Either they pay no attention to the practices themselves or their economic and political implications, or they distinguish political thinking - what should be done about something that is currently informal? - from economic and sociological reflection on the legitimacy of the phenomenon.

"Social" thinking on the sociological dimension of informal trade, i.e. the networks to which it gives rise, is interesting. Many studies invite reflection on the connection between the informal, the illegal, and the legitimacy of the informal, especially the different ways of representing the economic benefits or otherwise of informal activities by region, the history of a given merchandise in the region, and the family and regional links of the players involved in informal trade. Nevertheless, the thinking behind them remains clearly divided between a critique of the disappearance of informal trade in terms of its social dimension and the need to make it disappear in the name of reintegration in a calculatory mode of thought. The debate often revolves around this irreconcilable difference between a social representation of informal trade, interpreted as "conservative", and its hollow representation as a measurement vacuum to be filled.

Informality is thus likely to take on increasing importance - as a concept - as quantification itself becomes increasingly important for improving the governability of societies and governing them by what is, in effect, a regime of experts. Nevertheless, informal trade does have political significance: it is the material proof of the existence of other forms of measurement and evaluation in accordance with the risk involved, the nature of the traded product, and the relationship to property and to the buyers and sellers. These are political issues which present quantification does not address and which will disappear if informal trade is treated only as an object with no future.

The persistence of informal trade in societies that are increasingly quantified in order to render them governable goes hand in hand with the increase in control techniques and the laws which introduce them. No Customs code or legislation will specify systematically what needs to be done, in concrete terms, in order for it to be implemented on the ground. Unlike police forces, which act in response to an actual or attempted offence, the controlling action of the Customs services in particular, and the trade or wealth regulatory agencies in general, is systematic: control means procedures to be followed, whether the subject is a fraudster or not. The procedure itself is the control. Customs legislation remains fairly general, so that its application also involves action by administrative agencies. Informal trade thus brings us back to the concrete aspects of the law, the fact that the control technique itself - via accountancy, the container scanner, risk analysis, Customs valuation methods, and the Authorized Economic Operator - creates technical margins of legality.

\section{The papers presented in this special issue}

In the end, the problems of "Customs officials" and "researchers" turned out to be positive. Exchanging ideas with practitioners leads researchers towards an approach which, while not necessarily "applied thinking", nevertheless takes account of the existence of specific social demands such as taxation and security, and of the technical complexity of regulatory situations. In return, dialogue with researchers can change political and scientific representations of "informals", enabling practitioners to think through the effects of existing regulations and their ideological framework, and to reflect on future regulation. This special issue is a contribution to that dialogue.

The papers in this special issue provide several perspectives on informal trade in the Twenty First Century. 
First, Nancy Benjamin, Stephen Golub and Ahamadou Aly Mbaye, place informal trade in the context of regional integration in Africa. As economists, the authors are interested in quantifying informal trade. What is an advantage for informal traders - their invisibility in official figures - make borders a weakness: through statistical comparisons among neighbouring countries on average consumption per inhabitant and imports, the authors estimate the informal trade. The authors present case studies on specific commodities such as used cars, cotton, clothes, cigarettes, sugar, rice, and vegetable oil. It is important for any reader who is interested in cross-border informal trade to confront this material accuracy of the flow of goods, and to solve how one can concretely represent the adaptation strategies of merchants to political and economic asymmetries created by borders.

The regional context described by Benjamin, Golub and Mbaye is practically the "natural" context of informal trade in Africa, shaped by colonial borders, based on precolonial flows of traders and an incomplete contemporary regional integration of trade policies. The authors recall the role of colonial policies to create political and economic asymmetries through borders that have now become business opportunities. What the authors show is to what degree informal traders are aware of globalization by comparing the benefits of national trade policies. One can read what concretely means a national pricing or trade policy, and to which extent cross-border merchants adapt to it. African borders (and diverging trade and economic policies) fragment regional markets in warehouses areas and consuming areas. For informal traders, borders are an economic factor to develop their activities, which is similar with transnational companies and their adaptation strategies to national tax policies. As a consequence, some countries play a crucial role, as "entrepôt states", such as Benin, Togo and Gambia whose regulations encourage intra-regional trade to landlocked countries and protectionist neighbours such as Nigeria and Senegal. The borders have a key role in defining areas, countries, where the change of flow is also equivalent to a change of border crossing practices: what may enter legally in states-entrepôts from Asia may illegally exit to neighbouring countries. As shown by the authors, globalization is likely to increase inequalities, between informal traders whose trade horizon is the border area and those informal traders whose horizon is rather located in Asia.

This is the emergence of this fracture line that anthropologist Sylvie Ayimpam explores; among other phenomena she describes is an ethnography of trade in textiles between Brazzaville (Republic of the Congo) and Kinshasa (Democratic Republic of the Congo), two major capitals situated on either side of the Congo River. This ethnography addresses two major concerns. First, the border as a place of entanglement between the informality of business and the informality of control administrations: Sylvie Ayimpam builds on the informal practices as a reflection on the co-production of the rules adopted by civil servants, traders and smugglers and the way non-legal practices become "normal" for both sides. Second, the article shows how informal trade networks compete against each other, using the same logistical and transport networks for smuggling, as soon as states change their regulations. The prohibition of the entry of certain textiles from Asia in the Democratic Republic of the Congo has created new competition between West African textile merchants and women from the banks of the Congo River who have long controlled trade in Asian textiles between Brazzaville and Kinshasa. This competition can occur because informal traders and most carriers are well organized, and because informal traders are concerned about the predictability of their transactions. For instance, for informal traders, paying bribes is less important than the fluctuation in the amount of bribes.

Anthropologist Gordon Mathews, in his article, reveals similar concerns on the part of African merchants in Asia. This is perhaps counter-intuitive but governments and those who control the borders should consider that the informal is not so fluid or flexible. It can be the 
case when the situation is examined globally, with the view of markets' theories on fluidity and re-allocation of resources. At the individual level, however, this is not necessarily the case. Informality and its characteristics inspired by economics, such as fluidity and flexibility, occasionally make us forget that informal traders and their intermediaries are not as opportunistic and "liberal" as we want to believe; they are just as anxious to anticipate their lives as the others who are formal and have formalized their risks into their accountabilities. And informality is not so detached from competition either.

Considering informal as an "indistinct mass" that is only visible thanks to the freight it transports is sometimes based on the assumption that informal traders are marginal citizens who contribute little to national wealth. This is developed in the third article, written by anthropologists Peter Little, Waktole Tiki and Dejene Negassa Debsu, about the informal livestock trade in the Horn of Africa and the relation to taxation of any kind on cross-border routes. The authors locate informality within a major economic field, the livestock trade in the Horn of Africa which is the largest concentration of live animal trade in the world and is integrated in global markets. The authors confront the agendas of state agents and merchants to show how informal traders avoid several kinds of state coercion that includes taxation or security constraints. When governments have regarded the border as an opportunity to formalize the informal, in the course of flow, they failed. Policies such as money exchange limitations, installation of administrative and banking infrastructures at borders, extension of the border line as a "border zone," (where a certain amount of transactions are authorized without taxation to contain the informal trade first geographically then economically and politically) failed. These policy failures question the efficiency of borders as a monitoring institution. The policies that are currently being experimented are much more technical, such as special computer-wired cash registers that automatically collect information on sales for taxation assessment. These tools rely on particular forms of accounting, making the assumption of certain trade practices, accounting, fixed installation bureaus, etc - in short, a "modern" and "urban" vision of cross-border trade. We find here the technical effects of the control to generate informality by making some trade techniques eligible to administrative control. There is probably, as the authors note, a technical dimension related to these choices but also a sociological one. Do the pastoralists really belong to the city/nation? Are they as faithful to the community as one can expect from citizens? This is the very common "betrayal" of the merchants, the global suspicion against merchants that animated representations of merchants for centuries. What the authors say about pastoralists echoes a common representation of merchants as "nomads" who are unfaithful to the needs of the society that they take benefits with (Henaff, 1987) ${ }^{10}$. In fact, the authors show that the amount of the contribution of pastoralists throughout all their journeys (local taxes and bribes) are very important, multiplied because they pass the borders. They are not counted as a real contribution, however, as pastoralists are not necessarily seen as "belonging" to the territories they cross and whose borders delimit specific financial accountabilities.

There is an opposition between borders which are areas where wealth and its taxation are concentrated and the "center" of the country which is struggling to recover the public share of private wealth circulating. This opposition is exposed in another form in the article by Mathews, who connects China and Africa through the circulation of counterfeit goods and

\footnotetext{
${ }^{10}$ This is a very common representation. In his Laws, Plato would owe nothing to foreign merchants. In his ideal city, the Foreigner from Athens proposes to restrict import and exports in terms of the nature of goods and, above all, he does not impose any taxation on foreign trade. This is a bit strange for contemporary experts who think, on the contrary, that reducing tariffs is a way to increase international trade. The point Plato wanted to make clear is the fact that the city treasury must not depend on the taxation of long distance merchants and this is in line with the global closure of the city.
} 
the role of corruption in such circulation. The legal and moral status of copies and the meaning of "intellectual property" are questioned. Mathews demonstrates how informal trade, when embedded in globalization, tackles "rich" state certainties. In describing precisely the practices of informal traders, Mathews realizes the important knowledge that they deploy, their computational capabilities that are very precise although not formalized.

The question Mathews ultimately raises, however, is the moral dimension of the informality on several levels. The first is that informals are often perceived and represented as vectors of malevolence including the corruption of border officials or the infringement of intellectual property that is described in the article. Corruption and ethics do not seem to particularly affect informal traders, which ultimately increases the representation of these cross-border merchants as marginalized citizens, detached from the moral fabric of societies.

Reading Mathews raises a question: in what name should informal traders be required to be more moral than formal merchants? If the morality of their actions does not affect the informal traders (of legal or legitimate goods), it is probably because there is no more reason that this would be the case for them than for formal traders whose bad practices are equally known. Prohibiting goods such as CD copies or counterfeit luxury goods obviously raises more moral issues than the prohibition of drugs or counterfeit medicine: these goods are declared illegal by business actions at the global level when trademarks are registered, and not by societies that decide to prohibit a specific chemical substance and describe its composition in the law. Mathews shows that informal traders remain worried about being faced with illegal goods such as drugs, for example. The issues raised by Mathews - and how he responds to them - may seem provocative, but corruption, and the morality of piracy form the representations of border controls and, as such, they should be treated by governments. By reminding the raw and basic character of these informal practices, Mathews encourages us to take what informal traders say as facts of language which have their own effectiveness in representing the meaning of border control.

For example, as long as corruption continues to shape the representations of the border crossing, informal merchants - and even formal ones - will themselves be encouraged to choose this path because corruption can become predictable and allow them to build local connections. Accordingly, it reconstitutes a form of trust between stakeholders linked by the same crime and therefore the same secret. This form of trust, based on individual relationships and partially invisible, fits in with the form of trust usually adopted by informal traders to replace the law in standard trade relationships. Finally, concerning the piracy of goods, Mathews reports the words of an African merchant for whom trading counterfeited goods is "bringing the world to Africa." In saying this, this merchant reminds us that trade is the desire for diversity that drives someone beyond his own community, across social and geographical borders of his society, to bring back what is unknown and desirable. This simple evidence has not been contested by companies producing the original goods that are counterfeited; Mathews reports that one representative did not really care that the poor markets receive counterfeit goods since the original goods could not have been sold there.

Finally, Customs officers Chang-Ryung Han and Yeonho Kang who are also researchers specialized in criminology, and criminologist Hans Nelen describe the Korea Customs Service's response to shuttle trade between Korea and China and describe the constraints faced by a state agency at borders. This article provides what the others could not do as easily: the views of the control authorities. Two of the authors are from the Korean Customs, they had access to data, contact with Customs officers, and thus more freedom than other researchers. Few administrations are open to researchers and share field experiences. This article sincerely reflects this desire. The authors show how administrations have contributed to criminalize border crossing practices or even to increase the risk of 
encouraging shuttle traders to carry illegal goods. The authors also raise an interesting question regarding cross-border informal trade and its connection to globalization: its relation to economic crisis and the willingness of governments to make informal trade activities absorb the economic shocks and try to eradicate them as soon as the economic situation improves. Again, there is a form of flexibility and fluidity of informal trade, but imposed by the political authority. As such, the authors show the violent resistance capacity of informal traders against the will to submit or make them disappear. The role of the border as a restricted place of forced relationships between officials and merchants is thus crucial. The authors show that the repressive policies are generally not enforced by field officers who, for some of them, are afraid of violent reactions, and also perhaps because they feel mere empathy with the traders. This point is often missed in articles that suggest collusion between officials and informal traders only in the form of corruption. What the authors finally show here is that the border is a place where officials and merchants cannot help but to weave regular relationships and as such, the civil servants may be more committed to implement policies of negotiation more easily than policies of eradication.

\section{Concluding remarks}

Border agencies like Customs should differentiate between intentional smuggling and informal trade where non-compliance may be less intentional. Subsequently, Customs should consider the consequences of different approaches. A border agency that is more transparent, less corrupt, and willing to negotiate a reasonable solution will foster positive incentives for informal traders. Ultimately, this is not a normative discussion, but a discussion of reality, an informality reality. Nations that evolved and modernized accepted that, while it was not possible that all taxpayers paid, a sufficient number must, and thus the State was built. The early history of many countries is one of tax evasion by smugglers (Karras, 2010; Andreas, 2013) but a sufficient amount of trade transaction revenue was still collected to fund the policies and programmes of a stable government.

In our view, the concept of informality thus retains all its operational force, opening up an area for discussion between research and society on a phenomenon which survives regulation, sometimes benefits materially from it, and calls the action of the State in general into question, beyond moral or ideological judgments about corruption or economic legitimacy. The informal sector is of interest as a borderline situation for observing relations between society and the regulation of economic activity, reminding us that, in all places, taxation is negotiated; that such negotiation is a negotiation between politics and technique at various levels, both international and national; and that the officials responsible for regulation are located at the interfaces between these various areas of negotiation.

\section{Bibliography}

Andreas, P. (2013), Smuggler Nation: how illicit trade made America (New York, Oxford University Press).

Benbouzid, M. (1999), "Réseaux financiers et marchés parallèles de devises. Des Algériens dans l'économie informelle”, Revue européenne de migrations internationales, 15(2), pp. 123-39. 
Bourdieu, P. (1986), "La force du droit. Eléments pour une sociologie du champ juridique”, Actes de la recherche en sciences sociales, Vol. 64, No. 1, pp. 3-19.

Bredeloup, S. and J. Lombard (2008), “Mort de la fripe en Afrique ou fin d'un cycle ?”, Revue Tiers Monde, 194, pp. 1-22.

Cantens, T., Kaminski, J., Raballand, G., and Tchapa, T., (2014), "Customs, brokers, and informal sectors : a Cameroon case study”, World Bank Policy Research Working Paper 6788 (Washington, DC, The World Bank).

Cantens, T. (2013), “Other People’s Money and Goods: The Relationship Between Customs Officers and Users in Some Countries of Sub-Saharan Francophone Africa”, Sociologus, 63, pp. 37-58

Chiapello, Eve, “La construction comptable de l'économie”, Idées économiques et sociales 2/2008 (No. 152), pp. 26-34.

Cowen, D., 2010, “A Geography of Logistics: Market Authority and the Security of Supply Chains”, Annals of the Association of American Geographers, 100, 3, p.600-620.

Dongala J. (1993), “The informal sector trade among sub-saharan African countries: a survey and empirical investigation”. The Development Economies, XXXI-2, 151-172.

Flynn, D. (1997), “"We are the border”: identity, exchange, and the state along the BeninNigeria border”, American Anthropologist, 24(2), pp. 311-30.

Foucault, M. (1970), “Questions of Geography”, in Power/Knowledge: Selected Interviews and other Writings, 1972-1977, ed. C. Gordon (New York, Pantheon Books, 1980).

Gaignat de L'Aulnais, C.-F. (1718), Guide du commerce, contenant 4 parties ... Par C. F. Gaignat de Laulnais,... Despilly, Durand et Valade (Paris).

Gilligan, V. (2008), Breaking Bad, (New York, AMC).

Hansen, K. (2004), "Helping or Hindering? Controversies around the International SecondHand Clothing Trade”, Anthropology Today, 20 (4), pp 3-9.

Hart, K. (1973), “Informal Income Opportunities and Urban Employment in Ghana,” The Journal of Modern African Studies, 11(1), pp. 61-89. 
Hart, K. (2005), Formal Bureaucracy and the Emergent Forms of the Informal Economy, Research Paper No. 2005/11, UNU WIDER.

Hénaff, M. (1987), “Le Philosophe et le marchand”, MLN,102(4), 761-781.

Hoock, J. and P. Jeannin (1993). Ars Mercatoria: Handbücher und Traktate für den Gebrauch des Kaufmanns, 1470-1820. Schöningh.

ILO (International Labour Office (1972), Employment, Incomes and Equality - A Strategy for Increasing Productive Employment in Kenya (Geneva, International Labour Office).

Karras, A. L. (2010), Smuggling : contraband and corruption in world history, Plymouth, UK, Rowman \& Littlefield Publishers, Inc.

Klein, A. (1999), “The barracuda's tale: trawlers, the informal sector and a state of classificatory disorder of the Nigeria coast”, Africa 69 (4), pp. 555-74.

Lautier B. (1995). « Cinq questions à Hernando De Soto sur son ouvrage : L'autre sentier. La révolution informelle dans le Tiers Monde », Tiers-Monde, 36 (142), pp. 452-461.

Ledeneva Alena V., (2006), How Russia Really Works: The Informal Practices That Shaped Post-Soviet Politics and Business. Culture and Society after Socialism, Éditeur Cornell University Press.

Lesser, C. and E. Moisé-Leeman (2009), "Informal Cross-Border Trade and Trade Facilitation Reform in Sub-Saharan Africa”, OECD Trade Policy Papers, No. 86, OECD Publishing.

Lourenço-Lindell, I. (2004), "Trade and the Politics of Informalization in Bissau, GuineaBissau”, in K. Tranberg and M. Vaa, Reconsidering Informality. Perspectives from Urban Africa, Nordiska Afrikainstitutet, pp. 84-98.

Lusebrick, H.-J. (1979), “Images et représentations sociales de la criminalité au XVIIIe siècle: l'exemple de Mandrin”, Revue d'histoire moderne et contemporaine, 26, pp. 345-64.

MacGaffey J. (1987). Entrepreneurs and Parasites : the struggle for indigenous capitalism in Zaire. Cambridge University Press.

Martin, C., 2012, "Desperate Mobilities: Logistics, Security and the Extra-Logistical Knowledge of “Appropriation'”, Geopolitics, 17(2), p. 355-376. 
Meagher, K. (2013), Unlocking the Informal Economy: A Literature Review on Linkages Between Formal and Informal Economies in Developing Countries, No. 27, WIEGO Working Paper.

Michaels, R., (2009), “Comparative Law by Numbers? Legal Origins Thesis, Doing Business Reports, and the Silence of Traditional Comparative Law”, The American Journal of Comparative Law, Vol. 57, No. 4 (FALL 2009), pp. 765-795.

Mitra, S. and B. Kaminski (2012), Borderless Bazaars and Regional Integration in Central Asia: Emerging Patterns of Trade and Cross-Border Cooperation (Washington, The World Bank).

OECD, 2009, Engaging with High Net Worth Individuals on Tax Compliance.

Ødegaard C. (2008), "Informal Trade, Contrabando and Prosperous Socialities in Arequipa, Peru”, Ethnos, Vol. 73, Issue 2, pp. 241-66.

Ogien, Albert (2010), "La valeur sociale du chiffre”, Revue Française de Socio-Économie 1/2010 (No. 5), pp. 19-40.

Peraldi, M. (2001), ed., Cabas et conteneurs.

Peraldi, M. (2007), Aventuriers du nouveau capitalisme marchand. Essai d'anthropologie de l'éthique mercantile, FASOPO.

Pohit, S. and N. Taneja (2000), India's Informal Trade with Bangladesh: A Qualitative Assessment, Indian Council for Research on International Economic Relations, Working Paper 58.

Raballand, G. and E. Mjekiqi (2010), “Nigeria’s Trade Policy Facilitates Unofficial Trade but not Manufacturing”, ch. 6 in Volker Treichel (ed.) Putting Nigeria to Work: A Strategy for Employment and Growth, World Bank, Washington, D.C.

Renfrew, C. (1969), “Trade and culture process in European prehistory”, Current Anthropology 10, pp. 151-69.

Roitman J. (2004), Fiscal Desobedience: an Anthropology of Economic Regulation in Central Africa, Princeton University Press. 
Scheele, J. (2009), “Tribus, États et fraude: la région frontalière algéro-malienne”, Etudes rurales, 2009/2 No. 184, pp. 79-94.

Schneidera F., Andreas Buehnb A. and Claudio E. Montenegroc C. (2010), "New Estimates for the Shadow Economies all over the World”, International Economic Journal, 24 (4), pp 443-461.

Skornicki, A. (2006), “L’État, l’expert et le négociant : le réseau de la " science du commerce » sous Louis XV”, Genèses 65(4), 4-26.

Soto, H. de (2000), The Mystery of Capital: Why Capitalism Triumphs in the West and Fails Everywhere Else, London, Bantam.

Titeca, K. (2006), “Les Opec Boys en Ouganda, trafiquants de pétrole et acteurs politiques”, Politique Africaine 103, pp. 143-59.

Van Schendel, W. and Abraham, I. (2005), “Introduction: the Making of Illicitness”, in Van Schendel and Abraham (ed.), Illicit Flows and Criminal Things: States, Borders, and the Other Side of Globalization, Indiana University Press, pp. 1-37. 